\title{
The Effect of Service Quality in International Airport I Gusti Ngurah Rai on Satisfaction, Image, and Tourists Loyalty Who Visited Bali
}

\author{
Saroha Manulang, I Komang Gde Bendesa, and I Nyoman Darma Putra
}

\author{
School of Postgraduate Study \\ Doctorate Degree in Tourism Udayana University
}

Coressponding author: sarohamanullang@yahoo.co.id

\begin{abstract}
ARTICLE INFO
Received

23 October 2014

Accepted

05 February 2015

Available online

10 March 2015
\end{abstract}

ABSTRACT

\begin{abstract}
Airport are the first and the last contact point for tourists when they arrive at their holiday destination. Therefore, the airport facilities are a source of first impression that effect the quality expectations of the tourists on holiday activities. Bali as a world class tourism destination to develop and renovate the Ngurah Rai International Airport in order to improve quality of service in order to give higher satisfaction for tourists visiting Bali. Based on this study aims to determine (1) the effect of quality of service to tourists' satisfaction and the image of Bali tourism; (2) the effect of the image of tourism and the quality of service to the loyalty of tourists visiting Bali; (3) the effect of the satisfaction of tourists to the tourism image and loyalty of tourists visiting Bali; (4) the effect of indirect tourism image of the traveler loyalty through satisfaction of tourists; (5) service quality indirectly traveler loyalty through tourism image; and (6) to determine the rating opinion on the quality of service Bali's Ngurah Rai International Airport. Population of this research was all foreign tourists visiting Bali through Ngurah Rai Airport at the time of the research. The research samples included 348 respondents were chosen with nonprobability sampling. accidental sampling technique. Data collected through questionnaires, interviews and observations. The collected data were analyzed with SERVQUAL, Importance Performance Analysis (IPA), and Structural Equation Modelling (SEM) for hypothesis testing. The results showed (1) the quality of service Bali's Ngurah Rai International Airport is a positive effect on tourist satisfaction and the image of Bali tourism; (2) the image of tourism and service quality Bali's Ngurah Rai International Airport is a positive effect on loyalty rating; (3) The traveler satisfaction positive effect on tourism image and loyalty of tourists visiting Bali; (4) Tourism image positive effect on loyalty through satisfaction of tourists; (5) service quality Bali's Ngurah Rai International Airport affect the tourist loyalty through tourism image; and (6) overall rating opinion on the quality of service in the high category, with the highest quality opinions contained in the tangible dimension and the opinion of the lowest quality is below average are in the dimension of reliability.
\end{abstract}

Keywords: Service Quality, Satisfaction, Tourism Image, Loyalty, I Gusti Ngurah Rai International Airport.

\section{Introduction}

\section{Background}

Service is a very important tool in tourism activities, not only as a departure and arrival facilities people travel frequently but also with

http://ojs.unud.ac.id/index.php/eot regard to the image of a travel destination. Bali's Ngurah Rai International Airport has just completed the development and renovation. This was done because the airport is the first contact and the last tourists encountered while on vacation to a destination. 
Therefore, the airport facilities are a source of the first and last impression that affect the quality expectations of the tourists on holiday activities.

Increased tourist arrivals to Bali occurs because the appeal of nature and culture for tourists. In addition, the increase also occurs because of infrastructure and other facilities continues to grow. Ngurah Rai Airport just expand and improve its facilities with the funds of Rp 2.8 trillion, which includes the expansion of arrival and departure terminals of domestic and international. With the completion of the renovation of the Ngurah Rai Airport in 2013, increasing its capacity from 14 million passengers to 25 million passengers, an increase of $78.57 \%$. This figure is the largest airport capacity in Indonesia today. (Special Class I Immigration Office Ngurah Rai Bali, 2013).

Bali as a world class tourism destination to develop and renovate the Ngurah Rai International Airport in order to improve the quality of its services to provide a higher satisfaction for tourists visiting Bali. Besides improving the quality of service at Bali's Ngurah Rai International Airport is expected to raise the image of Bali tourism, which in turn may increase the loyalty of tourists to visit Bali.

To continue to increase tourist arrivals, the government has issued Presidential Regulation No. 69 Year 2015 regarding Visa Free visits. In the second article explained that the visit Visa Exemption granted to a Foreigner nationals of certain countries and the government of the special administrative regions of certain countries with regard to the principle of reciprocity and the principle of benefit. According to this regulation, Foreign nationals of certain countries are exempted from the obligation to have a visit visa to enter Indonesian territory in order to visit Travel.

Service is a very important tool in tourism activities, not only as a departure and arrival facilities people travel frequently but also with regard to the image of a travel destination. According to Martín-Cejas (2006) airport is not the final destination of the tour, but the airport is only a transit point between the place of origin of tourists to a tourist destination.

http://ojs.unud.ac.id/index.php/eot
Thus, the airport will bring traveler's first impression will be a tourist destination visited. Therefore, existing services at the airport as a whole, must be able to foster a positive image of a tourist destination and according to result of Airport Council International (ACI) about Airport Service Quality (ASQ) that's Ngurah Rai International Airport the best third in the world with category 15 million until 25 million passangers.

The image of a tourist destination is one of the reasons tourists to visit these destinations. The existing image in the minds of tourists is not always in tune with the real conditions of the destination itself so, the image of the destination has the potential to affect the least competitive destination. (LeBlanc and Nguyen, 1996). Travel image actually can be formed from a set of beliefs, ideas, inspiration, perception and attitude of a person who obtained tourists on a tourist area (Weisesa, 2008).

\section{Research Objectives}

Research is an activity to search, explore, connect and predict an occurrence. Every study conducted has a clear purpose and direction. The purpose of this study are:

1. To analyze the impact of service quality Bali's Ngurah Rai International Airport on tourist satisfaction and the image of Bali tourism.

2. To analyze the effect of tourism image and service quality Bali's Ngurah Rai International Airport to the loyalty of tourists visiting Bali.

3. To analyze the effect of tourist satisfaction and loyalty to the tourism image of tourists visiting Bali.

4. To analyze the effect of indirect tourism image of the traveler loyalty through satisfaction of tourists.

5. To analyze the impact of service quality Bali's Ngurah Rai International Airport loyalty indirectly tourists through the tourism image.

6. To analyze the rating opinion on the quality of service Bali's Ngurah Rai International Airport. 


\section{Literature Review}

Consumer satisfaction is a particular response from consumers as a result of the evaluation of the gap between expectations and performance products Giesel \& Cote (cited by Manurung, 2009). While Mowen and Minor (2002) states that consumer satisfaction is an overall attitude shown consumers for goods or services after they obtain and use. It is an evaluative assessment post-election caused by the selection of special purchase and experience of using the goods or services.

\section{Quality of Service}

Service Quality is how far the difference between expectations and reality of the customers for the services they receive. Service Quality can be determined by comparing the perception of customers for the services they actually receive the service they expect. Quality of service becomes the main thing seriously considered by the company, which involves the entire resources of the company. To facilitate the assessment and measurement of service quality developed a service quality measurement tool called SERVQUAL (Service Quality). SERVQUAL is a multi-item scale that can be used to measure customer perceptions on the quality of services that includes five dimensions (Zeithami and Bitner, 2004).Zeithami and Bitner (2004) identified five (5 dimensions service quality are used by customers in evaluating quality of service. These five dimensions are tangible, empathy, reliability, responsiveness, and assurance.

\section{Satisfaction Traveler}

There are several definitions that are commonly used to describe customer satisfaction or customer satisfaction. Sadeh et al. (2012) defines satisfaction as a postconsumption evaluation in which an alternative is selected at least meet or exceed expectations. In short, these alternatives should be carried out as good as or exceeds what is expected. According to Archana and Subha (2012); Kotler and Keller (2012), consumer satisfaction is feeling happy or upset someone who comes from a comparison between the impression of the performance (results) of a product with many hopes.

\section{Citra Tourism}

Tourism image is a person's beliefs, thoughts and impressions based on the amount or specific information about the purpose, feeling, and as a reflection of the general perception in the mind of the individual (Inan, 2010: 4). According Konecnik (2004) the image of the tourist area destination is a set of beliefs, ideas, and impressions of people at the place and purpose of the tourist area. Meanwhile, according to Lopes (2011) the image of a tourist destination is an expression that includes all the knowledge, prejudices, imagination and emotional mind an individual or group on specific tourist sites. According Konecnik (2004) image dimensions attractions include beliefs, ideas and concepts. Trust is a belief that the other party statements can be relied upon to fulfill its obligations. Distrust can occur in line with the lack of information in the planning and performance measurement.

\section{Loyalty Traveler}

What is meant by tourists loyalty is a commitment to defend in depth to re-purchase or come back to the area attractions or services consistently selected in the future, although the influence of the situation and marketing efforts have the potential to cause changes in traveler behavior (Mosahab, Mahamad and Ramayah, 2010; Som and Badarneh, 2011; Movafegh and Movafegh, 2013). From these definitions it can be said that the loyal customers who have some kind of fanaticism that is relatively permanent in the long term for a product / service or a company that has become the choice. While Saha and Theingi (2009) stated that it has become apparent that customer satisfaction is now no longer the key factor of success the company but customer loyalty is the key to a successful dominant business. Customer loyalty is defined as customers who are satisfied with the products or services of the company and they become a word-ofmouth advertisers who enthusiastically. $\mathrm{He}$ further expand the loyalty not only on the product or service, but also the whole portfolio products and services as part of a lifetime, or in other words, brand loyalty forever. 


\section{Theoretical framework}

Frame of mind is the result and synthesis of theory and literature review associated with the problems encountered in the formulation of the research problem. Frame of mind in this study based on the premise that everything done by humans is always based on a certain motivation and interest, which will affect the individual's performance. According Sugiono (2012) in forming a theory group that needs to be put forward in the preparation of the frame of mind to make a hypothesis must be determined first research variables. In this study, there are four (4) research variables consisted of airport service quality, tourism image, tourist satisfaction and loyalty rating.

\section{Hypotheses}

$\mathrm{H}_{1}$ : Quality of service Bali's Ngurah Rai International Airport is a positive effect on tourist satisfaction and the image of Bali tourism.

$\mathrm{H}_{2}$ : The image of the tourism and service quality Bali's Ngurah Rai International Airport is a positive effect on the loyalty of tourists visiting Bali

$\mathrm{H}_{3}$ : Traveler satisfaction has positive influence on the image of Bali tourism.

$\mathrm{H}_{4}$ : Citra tourism indirectly positive effect on the tourist loyalty through satisfaction of tourists.

$\mathrm{H}_{5}$ : The quality of service Bali's Ngurah Rai International Airport is indirectly positive effect on the tourist loyalty through tourism image.

$\mathrm{H}_{6}$ : onsidering the formulation of this problem is the formulation of the problem that does not have to be proved by testing the hypothesis, but explored through interviews to explain the rating opinion on the quality of service Bali's Ngurah Rai International Airport, making this the sixth problem formulation does not require hypothesis.

\section{Methodology}

This study uses a quantitative research dat-supported by qualitative data. Quantitative research methods used to obtain the results of in-depth evaluation and comprehensive, this approach is used to handle data that is quantitative (numbers). While qualitative methods are used to be based on the consideration that the symptoms of this research is a process that is done by studying the behavior or activities of the actors involved in it (Sugiyono, 2012). While in Tashakkori and Teddlie Creswell (2010: 77) argues that the results of quantitative research does not have to be a confirmation of qualitative research results, and vice versa. Most studies that use this approach to generate numerical data and narrative data in the same answer research questions.

The population in this study were all tourists visiting Bali through Ngurah Rai Airport at the time of the study conducted in August 2014 to March 2015. In accordance with modeling Structural Equation Modeling (SEM), has chosen sample of 348 respondents using purposive sampling technique. Data used in this research is quantitative data and qualitative data. Based on the source, the data of this study distinguished between primary data obtained from questionnaires, interviews and documentation as well as secondary data obtained from various sources.

Data were collected through questionnaires were analyzed using analysis techniques Equation Modeling Structural equation modeling (SEM) using AMOS program package SPSS version 22 and 21. After the data were analyzed with SEM structural equation model, the qualitative analysis through interviews and analysis description SERVQUAL consists of analysis of the conformity level, the analysis of customer satisfaction index and importance Performance Analysis (IPA).

\section{Results and Discussion}

\section{Characteristics of Respondents}

The results showed respondents with male gender as many as 185 people or $53.16 \%$, while respondents with female sex as much as 163 people or $46.84 \%$. This shows the male respondents is larger than the female respondents, but the difference was not significant. Respondents age 17-26 years as many as 69 people or $19.83 \%, 27-36$ years as many as 127 people or $36.49 \%$, 37-46 years as many as 96 people or $27.59 \%$ and the 46 years and over as many as 56 people or $16.09 \%$. 
This shows that the majority of respondents in this study age was 27-36 years. The data show that the age of tourists who traveled in Bali highest is aged 27-36 years is $36.49 \%$, followed by the age of $37-46$ years is $27.59 \%$. If the age range of 27-46 years are summed into as many as $64.08 \%$, which means that the majority of foreign tourists to Bali has a productive age, which is trying to find a balance between work and leisure.

Respondents with a description of a visit to Bali one time as many as 17 people or $4.89 \%$, two times as many as 23 people or $6.61 \%$, three times as many as 124 people or $35.63 \%$, four times as many as 32 people or $9.20 \%$, 5 times as many as 89 people or $25.57 \%$ and $>5$ times as many as 63 people or $18.10 \%$. This shows that the majority of respondents in this study has a description of a visit to Bali three times, this is possible given the multiple increase in the quality of the existing infrastructure in the island tourist attraction, thus increasing the interest of tourists to visit. Based on the above data it can be seen foreign tourists visiting Bali more than 3 times in the top 89\%. The reason they continue to visit Bali, among others: The appeal of Bali tourism and the improvement of facilities and infrastructure at Bali's Ngurah Rai International Airport. While the origin of tourists who were respondents in Asia include as many as 84 people or $24.14 \%$, Australia 98 people or $28.16 \%$, of Europe as many as 77 people or $22.13 \%$, USA as many as 53 people or $15.23 \%$ and the other 36 people sebnyak or $10.34 \%$. Based on this it can be concluded that the majority of respondents in this study merupawan tourists who come from Australia, this is possible given the distance between Bali and Australia are not too far away, so tourists it easier to fill the vacation time.

\section{Analysis Results Full SEM Model}

After the models were analyzed through Confirmatory Factor Analysis and seen that each variable can be used to define a latent constructs, then a full-SEM models can be analyzed. Results of data processing with the AMOS program can be seen in Figure 5.1 below:

Figure 1. Structural Equation Model

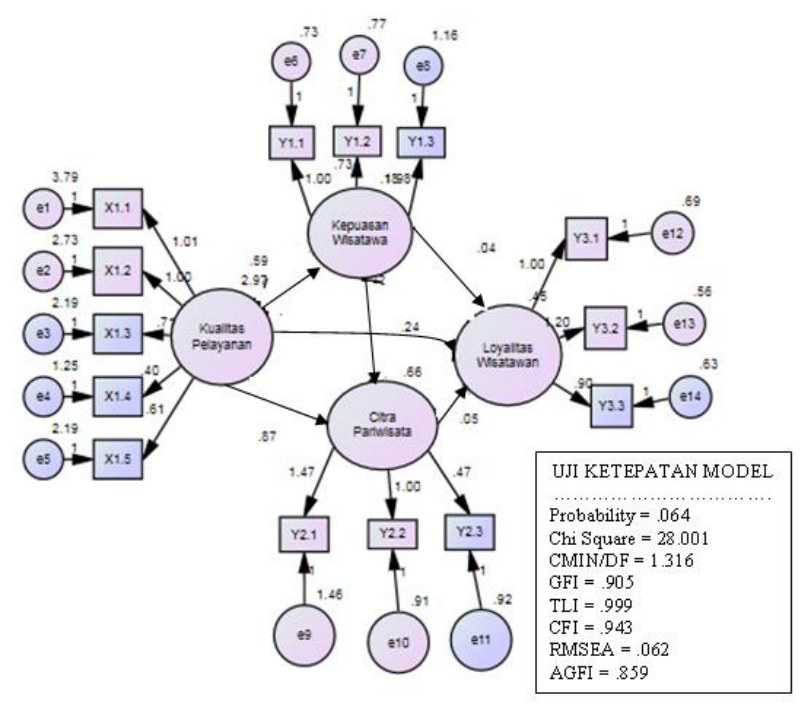

Source: Primary data are processed, 2015

Results of testing the suitability of the model in Figure 5.1 shows the chi-square value of 28.001 and the values of a probability of 0.64 which was above the limit of significance is 0.05 . in addition, an index measuring the value of the suitability of the model include GFI (0.905), AGFI (0.859), TLI (0.999), CFI (0.943), RMSEA (0.062), and CMIN / DF $(1,316)$ are in the range of expected values (Table 5.1). All this shows that there is no difference between the sample covariance matrix and covariance matrix estimated from the population so full model SEM is acceptable.

Table 1. Structural Equation Model Testing Results

\begin{tabular}{|c|c|c|c|}
\hline $\begin{array}{l}\text { Goodness } \\
\text { of Fit } \\
\text { Measure }\end{array}$ & $\begin{array}{l}\text { Cut off } \\
\text { Value }\end{array}$ & $\begin{array}{l}\text { Result } \\
\text { s } \\
\text { Model }\end{array}$ & $\begin{array}{c}\text { Evaluatio } \\
\text { n Model }\end{array}$ \\
\hline $\begin{array}{l}\text { Chi Square } \\
\left(\lambda^{2}\right)\end{array}$ & $\begin{array}{l}\text { Expecte } \\
\mathrm{d} \text { to be } \\
\text { small }\end{array}$ & 28,001 & Good \\
\hline $\begin{array}{l}\text { Significanc } \\
\mathrm{e} \\
\text { Probability } \\
(p)\end{array}$ & $\geq 0,05$ & 0,064 & Good \\
\hline RMSEA & $\leq 0,08$ & 0,062 & Good \\
\hline GFI & $\geq 0,9$ & 0,905 & Good \\
\hline AGFI & $\geq 0,9$ & 0,859 & Enough \\
\hline CMIN/DF & $\leq 2,00$ & 1,316 & Good \\
\hline TLI & $\geq 0,95$ & 0,999 & Good \\
\hline CFI & $\geq 0,94$ & 0,943 & Good \\
\hline
\end{tabular}

Source: Primary data are processed, 2015. 


\section{Hypotheses Testing}

Hypothesis testing is done by observing the probability (p) the estimation regression weight of structural equation models (Appendix 5). Estimates regression weight of structural equation model of service quality influence Ngurah Rai International Airport Good to tourist satisfaction, tourism image and tourist loyalty shown in Table 5.2. if the p-value of more than 0.05 , then the hypothesis is accepted.

Table 2. Structural Model Hypothesis Test Results

\begin{tabular}{|c|c|c|c|c|c|}
\hline $\begin{array}{l}\text { Hypo } \\
\text { thesis }\end{array}$ & $\begin{array}{l}\text { Directions } \\
\text { Line }\end{array}$ & $\begin{array}{l}\text { egressior } \\
\text { pefficient }\end{array}$ & C.R & $\begin{array}{c}\mathrm{p}- \\
\text { Value }\end{array}$ & $\begin{array}{c}\text { Raw } \\
\text { coefficient }\end{array}$ \\
\hline \multirow[b]{2}{*}{ H1 } & \multirow{2}{*}{$\begin{array}{l}\text { Quality } \\
\text { Service } \\
\text { Bali's } \\
\text { Ngurah Rai } \\
\text { International } \\
\text { Airport } \rightarrow \\
\text { Satisfaction } \\
\text { Rating and } \\
\text { Citra } \\
\text { Tourism }\end{array}$} & 0,591 & 5,190 & 0,000 & 0,811 \\
\hline & & 0,867 & 6,217 & 0,000 & 0,620 \\
\hline \multirow[b]{2}{*}{$\mathrm{H} 2$} & \multirow{2}{*}{$\begin{array}{l}\text { Citra } \\
\text { Tourism and } \\
\text { Service } \\
\text { Quality Bali } \\
\text { Ngurah Rai } \\
\text { International } \\
\text { Airport } \rightarrow \\
\text { Loyalty } \\
\text { Traveler }\end{array}$} & 0,054 & 2,220 & 0,023 & 0,100 \\
\hline & & 0,217 & 2,407 & 0,016 & 0,188 \\
\hline \multirow[b]{2}{*}{$\mathrm{H} 3$} & \multirow{2}{*}{$\begin{array}{l}\text { Traveler } \\
\text { Satisfaction } \\
\text { and Loyalty } \\
\text { Tourism } \\
\text { Citra } \rightarrow \\
\text { Travelers } \\
\end{array}$} & 0,243 & 5,234 & 0,000 & 0,707 \\
\hline & & 0,044 & 2,536 & 0,015 & 0,153 \\
\hline $\mathrm{H} 4$ & $\begin{array}{l}\text { Tourism } \\
\text { image of } \\
\text { Loyalty } \\
\text { Traveler } \rightarrow \\
\text { Through } \\
\text { Satisfaction } \\
\text { Rating }\end{array}$ & 0,013 & 6,385 & 0,000 & 0,071 \\
\hline H5 & $\begin{array}{l}\text { Quality } \\
\text { Service } \\
\text { Bali's } \\
\text { Ngurah Rai } \\
\text { International } \\
\text { Airport } \rightarrow \\
\text { Loyalty } \\
\text { Travelers } \\
\text { Through } \\
\text { Citra } \\
\text { Tourism }\end{array}$ & 0,012 & 5,344 & 0,000 & 0,019 \\
\hline
\end{tabular}

http://ojs.unud.ac.id/index.php/eot
Based on the estimated regression weight of structural equation model in Table 5.2, the results hypotheses can be summarized as follows:

a. Variable Quality Service Bali's Ngurah Rai International Airport is a positive effect on satisfaction Travelers. This is reinforced by the value that is positive regression coefficient of 0.591 and 0.867 , the value of the raw coefficient (standardize coefficient) of 0.811 and 0.620 , the value of the critical ratio (CR) of 5.190 and 6.217 (greater than 2 ) as well as the probability value (p) of 0,000 which is smaller than the significance level $(\alpha)$ is set at 0.05 . Thus, the hypothesis 1 (H1): "Quality of service Bali's Ngurah Rai International Airport is a positive effect on tourist satisfaction and the image of Bali Tourism" supported (unacceptable). The results support the research conducted RP and Sinambela (2011) concluded that the quality of services provided Snowbay Waterpark TMII proved positive and significant impact on customer satisfaction Snowbay Waterpark this area. This means that the quality of services provided to the satisfaction felt by both customers Snowbay Waterpark. Movafegh and Movafegh research (2013) shows that service quality has positive influence on customer satisfaction in the tourism industry. The same is also evidenced by Ali and Howaidee (2012); Hossain (2012); AlAbneh (2013) who concluded the service quality in the tourism destination affects the tourist satisfaction. Parasuraman (2009)(Parasuraman, 2009) noted with satisfaction as a customer evaluation of the service in relation to whether the service can meet the needs and expectations. Satisfaction can be associated with feelings of pleasure (pleasure) to services. It means that customer satisfaction is the degree to which the perceived service quality to meet expectations if the quality of service below expectations, customers feel dissatisfied. If performance meets expectations, then the customer is satisfied. The results support the research conducted Rahayu (2014) proved that koalitas services have a relationship with the image of the service provider. It is also raised by Rahadhini (2013) who in his research concluded that 
the quality of service received by tourists in sights pennant Boyolali Tratar positively associated with tourism image.

b. Tourism and Variable Image Quality Service International Airport Ngurah Rai Bali influence on Loyalty Traveler. This is reinforced by the regression coefficient is positive at 0.054 and 0.217 , the value of the raw coefficient (standardize coefficient) of 0.100 and 0.188 , the value of the critical ratio (CR) of 2,220 and 2,407 (greater than 2 ), as well as the probability value (p) amounting to 0,023 and 0,016 smaller than the significance level $(\alpha)$ is set at 0.05 . Thus, the hypothesis 2 (H2): "The image of the tourism and service quality Bali's Ngurah Rai International Airport is a positive effect on the loyalty of tourists visiting Bali" supported (unacceptable). The results support the research conducted Rahadhini (2013) shows the image of attraction positive effect on the tourist loyalty. Likewise, the research Rahayu (2014) shows the image of an effect on loyalty. Attraction image is a complex perception of a consumer (visitors) to attributes that stand out from the attraction. Good image of tourism is very important for the continuity of a tourist attraction, as it will lead to an influence on all the elements that exist in the tourist destination. Tourism image is a good impression of the company formed from the process at any time information from a variety of trusted sources of information.

c. Travelers Satisfaction variable positive effect on the image of Tourism and Loyalty Travelers who viewed Bali. This is reinforced by the regression coefficient is positive at 0,243 and 0,044 , the value of the raw coefficient (standardize coefficient) of 0.707 and 0.153 , the value of the critical ratio (CR) of 5,234 and 2,536 (greater than $2)$, as well as the probability value (p) 0,000 and 0,015 smaller than the significance level $(\alpha)$ is set at 0.05 . Thus, the hypothesis $3(\mathrm{H} 3)$ : "traveler satisfaction has positive influence on tourism image and loyalty Travellers who viewed Bali" supported (unacceptable). Results of this study was supported by research Sulistiyani (2010) concluded that the effect on loyalty traveler satisfaction rating. Rahadhini

http://ojs.unud.ac.id/index.php/eot
(2013) shows the influence on loyalty traveler satisfaction rating. According Wibowo and Yuniawati (2007) the increasing number of tourists associated with the added value that they get in the form of knowledge and cultural experience and satisfaction, which ultimately may increase the chance to come back. According to Dewi (2012: 39) various empirical research shows that tourist satisfaction can help increase the number of tourist arrivals to the destination.

d. Tourism Citra variable positive effect on loyalty Travelers Through Satisfaction Rating. This is reinforced by the regression coefficient is positive at 0,013 , the value of the raw coefficient (standardize coefficient) of 0.071 , the value of the critical ratio (CR) of 6.385 (greater than 2), as well as the probability value $(p)$ of 0.000 which is smaller than significance level $(\alpha)$ is set at 0.05 . Thus, the hypothesis 6 (H6): "The image of tourism indirectly positive effect on the tourist loyalty through satisfaction of tourists" supported (unacceptable). The results support the research conducted Rahadhini (2013) states the importance of customer satisfaction as mediating variables become important information for the managers and entrepreneurs in optimizing visitor loyalty. Customer loyalty (visitors) can occur when consumers were satisfied beforehand, and to realize that dissatisfied customers need for the formation of a positive image of the destination. Research Rahayu (2014) also shows the image of a positive effect on loyalty through satisfaction.

e. Variable Quality Service Bali's Ngurah Rai International Airport is a positive effect on loyalty Travelers Through Tourism Citra. This is reinforced by the regression coefficient is positive at 0,012 , the value of the raw coefficient (standardize coefficient) of 0.019 , the value of the critical ratio (CR) of 5.344 (greater than 2), as well as the probability value $(p)$ of 0.000 which is smaller than significance level $(\alpha)$ is set at 0.05 . Thus, the hypothesis 7 (H7): "Quality of service Bali's Ngurah Rai International Airport is indirectly positive effect on the loyalty of tourists through the tourism image" supported (unacceptable). The 
results support the research conducted Rahadhini (2013) showed that the image of the attraction Bannerman Tlatar Boyolali significant impact on visitor satisfaction Tlatar pennant Boyolali. Results of this study was supported by research Rahayu (2012) which shows that the image has a positive influence on satisfaction. It has been mentioned in advance that service quality affects the loyalty rating (Ali and Howaidee, 2012; Hossain, 2012; AlAbneh, 2013; Movafegh and Movafegh, 2013). Meanwhile, in building a good image there are several relevant factors to be studied further. Meenaghan and Shipley (1999) pointed out the importance of communication in improving the image of tourism. It is also stated by Graeff Judith A (2006), which are more specifically discussed the importance of the promotion of tourism in building an image.

\section{Effect of Variable Inter Research}

In a structural equation involving many variables and paths between variables, there are significant among variables that include direct influence, indirect influence and total influence. Between variables influence is reflected directly in the output modeling SEM, the results of the standard value effect. Influence between variables, namely direct influence, indirect influence and total influence is presented in Table 3.

Table 3. Between Variables Influence

\begin{tabular}{|c|c|c|c|c|}
\hline \multicolumn{2}{|c|}{ Variables } & \multirow{2}{*}{$\begin{array}{l}\text { Direct } \\
\text { Impact }\end{array}$} & \multirow{2}{*}{$\begin{array}{c}\text { Indirect } \\
\text { Influence }\end{array}$} & \multirow{2}{*}{$\begin{array}{l}\text { Effect } \\
\text { of } \\
\text { Total }\end{array}$} \\
\hline Independent & Dependent & & & \\
\hline $\begin{array}{l}\text { Quality } \\
\text { Service } \\
\text { Bali's } \\
\text { Ngurah Rai } \\
\text { International } \\
\text { Airport }\end{array}$ & $\begin{array}{l}\text { Satisfaction } \\
\text { Travelers }\end{array}$ & 0,811 & & 0,811 \\
\hline $\begin{array}{l}\text { Quality } \\
\text { Service } \\
\text { Bali's } \\
\text { Ngurah Rai } \\
\text { International } \\
\text { Airport }\end{array}$ & $\begin{array}{l}\text { Citra } \\
\text { Tourism }\end{array}$ & 0,620 & & 0,620 \\
\hline $\begin{array}{l}\text { Citra } \\
\text { Tourism and }\end{array}$ & $\begin{array}{l}\text { Loyalty } \\
\text { Travelers }\end{array}$ & 0,100 & 0,013 & 0,113 \\
\hline $\begin{array}{l}\text { Service } \\
\text { Quality Bali } \\
\text { Ngurah Rai } \\
\text { International } \\
\text { Airport }\end{array}$ & & 0,188 & 0,012 & 0,200 \\
\hline $\begin{array}{l}\text { Satisfaction } \\
\text { Travelers }\end{array}$ & $\begin{array}{c}\text { Citra } \\
\text { Tourism }\end{array}$ & 0,707 & & 0,707 \\
\hline $\begin{array}{l}\text { Satisfaction } \\
\text { Travelers }\end{array}$ & $\begin{array}{l}\text { Loyalty } \\
\text { Travelers }\end{array}$ & 0,153 & & 0,153 \\
\hline
\end{tabular}

http://ojs.unud.ac.id/index.php/eot
In accordance with the results of the direct effect standardize, greatest direct influence on service quality variable Bali's Ngurah Rai International Airport to the satisfaction of tourists amounted to 0.811 , then the effect on the image of the tourism traveler satisfaction by 0.707 and influence service quality Bali's Ngurah Rai International Airport on the image of tourism amounted to 0.620 , In addition, it also occurs directly influence variables tourism image and service quality Bali Ngurah Rai International Airport to the loyalty rating of 0.100 and 0.188 , and influence traveler loyalty satisfaction rating of 0.153 . Here we see that the variables that directly affect the most dominant is the variable quality of service Bali's Ngurah Rai International Airport to satisfaction $(81.1 \%$ ), while the weakest variables that have a direct effect on the tourism image is variable traveler loyalty $(10 \%)$.

Based on the value standardize direct effect, it is known that the indirect effect between variables occurs at a variable positive effect on the tourism image of tourist loyalty through satisfaction rating of 0.071 and quality service Bali's Ngurah Rai International Airport is a positive effect on the loyalty of tourists through the tourism image of 0.019 . Here we see that the variables that influence most dominant indirect positive effect on the tourism image of tourist loyalty through satisfaction of tourists $(7.1 \%)$. From this data, indicated that in an effort to increase the loyalty of tourists, then the variable Quality of Service Bali Ngurah Rai International Airport and tourist satisfaction has the most powerful influence of the other variables.

\section{Analysis Results SERVQUAL}

To determine the dimensions that should be corrected or improved in order to better satisfy tourists, then NIK $_{\text {performance and }}$ NIK $_{\text {importance }}$ mapped in a Cartesian diagram. Mapping to $\mathrm{NIK}_{\text {performance }}$ and $\mathrm{NIK}_{\text {importance }}$ research results can be seen in the following diagram: 


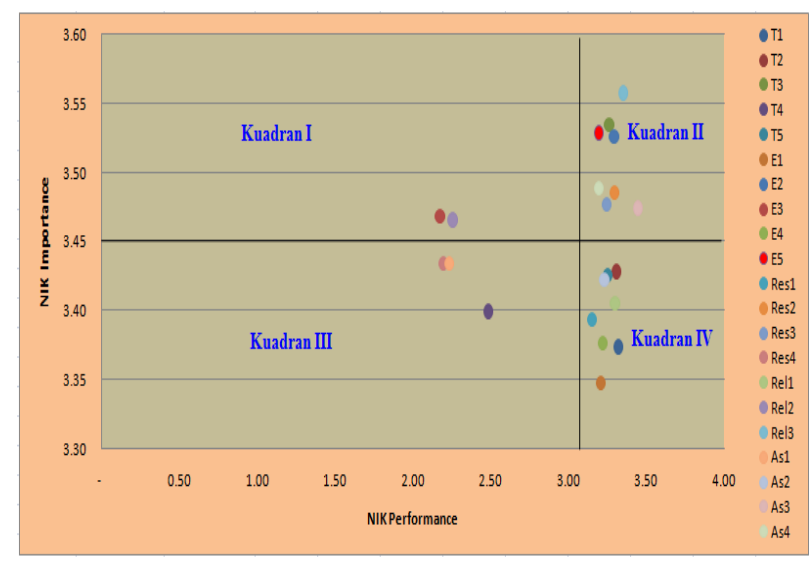

Figure 2. Mapping Service Quality

Dimensions Indicators I Gusti Ngurah Rai Airport Bali

Source: Data Answer Respondents were processed, 2015.

Based on Cartesian diagram as shown in Figure 5.2, it can be mapped indicators of quality of service Bali's Ngurah Rai International Airport as follows:

\section{Quadrant IV}

The indicators are in Quadrant IV consists of:

a. T1 indicators: Appearance airport employees who are ready to help and professional

b. T2 indicator: Equipment, fixtures and modern facilities

c. T5 indicators: a comfortable waiting room

d. Indicator E1: Officers airports can understand the needs of tourists

e. E4 indicator: Officers airports put the interests of tourists

f. RES1 indicators: Readiness airport personnel in serving tourists

g. Indicators Rel 1: Officers airports can work quickly

h. AS2 indicators: Tourists feel safe while in the airport

Quadrant IV shows that the level of importance (importance) or tourists expectations low, but the performance (performance) service Bali's Ngurah Rai International Airport is already high. Thus the indicators in this quadrant have given satisfaction to tourists service users Bali's Ngurah Rai International Airport.

\section{Quadrant III}

Indicators that are in quadrant III consists of:

a. Indicators AS1: Officers airport was able to answer every question of foreign tourists

b. Indicators Res4: Officers airports provide information that is clear and easily understood by tourists

c. Indicator T4: Board instructions (information board, desk, etc.) to help tourists

Quadrant III shows that the level of importance (importance) or tourists expectations low, and performance (the performance) service Bali's Ngurah Rai International Airport is also low. Thus the indicators in this quadrant is not very rewarding for tourists service users Bali's Ngurah Rai International Airport. But the tourists do not mind it, because it was considered not too important.

\section{Quadrant II}

The indicators are in Quadrant II consists of:

a. Indicators Rel3: Officers airports provide good information and clear

b. Indicators Res3: Officers respond quickly to complaints of tourists airports

c. Indicator E5: Services in the State of origin of tourists do not differentiate

d. Indicator T3: Condition airport environment clean

e. Indicator E2: Officers airport attentively treat tourists

f. Indicators AS4: Officers airports demonstrated the ability and knowledge of things done

g. Indicators res2: Willingness airport duty to help tourists

h. AS3 indicator: The clerk was friendly and courteous airport so travelers feel confident

Quadrant II shows that the level of importance (interest) or the high expectations of tourists, and performance (the performance) service Bali's Ngurah Rai International Airport is also high. This means that the indicators in this quadrant is very important for tourists and the service users Bali's Ngurah Rai International Airport has given good service so as to satisfy the tourists.

e-ISSN: 2407-392X. p-ISSN: 2541-0857 


\section{Quadrant I}

The indicators are in Quadrant $I$ is composed of:

a. Indicator E3: Officers contacted the airport easily tourists

b. Indicators rel2: Officers airports fulfill the promise (timely)

Quadrant I shows that the level of importance (importance) or tourists expectations high, but the performance (performance) service Bali's Ngurah Rai International Airport is still low. This means that the indicators in this quadrant is very important for tourists service users, but Bali's Ngurah Rai International Airport not give good service so as not to satisfy tourists.

As previously noted, in particular the analysis of SERVQUAL Analysis Importance Performance Analysis (IPA) to determine the service quality indicators Bali Ngurah Rai International Airport anywhere that has not been in line with expectations of tourists. Based on the results of IPA analysis that has been done, there are some indicators that do not meet the expectations of tourists, but the only indicators that are in quadrant 1 are to be improved.

The indicators are in Quadrant $I$ is composed of:

a. Indicator E3: Officers contacted the airport easily tourists

b. Indicators rel2: Officers airports fulfill the promise (timely)

Both indicators have a level of importance (interest) or the high expectations of tourists, but the performance (performance) service Bali's Ngurah Rai International Airport is still low. This means that both indicators are very important for tourists, but Bali's Ngurah Rai International Airport not give good service so as not to satisfy tourists.

Given two indicators that are in Quadrant I is that has been described above, have not given satisfaction to tourists, while foreign tourists consider important indicators of satisfaction. Therefore, the expected service Bali's Ngurah Rai International Airport can improve both indicators are in Quadrant I is not give satisfaction to tourists.

http://ojs.unud.ac.id/index.php/eot
Efforts to improve the performance of the two indicators is that the added officers at the airport and placed at strategic places easily seen by tourists so that the tourists easily contact airport personnel in time of need assistance / help. Besides that airport officials briefed so as not to give appointments or informs something to tourists that can not be fulfilled.

\section{Limitations of the research}

In this research, there are various limitations, which are as follows:

1. This research was conducted variable quality of service, satisfaction of tourists, tourism image, and the loyalty of tourists visiting Bali through Ngurah Rai International Airport, the conclusions obtained from this study can not be generalized for the entire service.

2. This study focuses on service quality, especially with regard to internal resources and not extended to the external service coverage.

3. The results of hypothesis testing is only as a causal relationship between the construct of quality of service to the satisfaction of tourists, tourism image and tourist loyalty. These findings suggested that replication of research conducted by the experimental design so that the nature of the relationship will be more accurate.

4. Resource persons in this study is limited to foreign tourists by taking the entire population of foreign tourists visiting Bali through Ngurah Rai Airport at the time of the study. To test the consistency of the findings is recommended for replication by using sources of domestic travelers and comparisons on some service in Indonesia and overseas.

\section{Conclusion and Recommendation}

\section{Conclusion}

Based on the results of research and discussion that has been raised, it can be concluded the following:

1. Quality of service Bali's Ngurah Rai International Airport is a positive effect on tourist satisfaction and the image of Bali 
tourism. Good service quality can provide a sense of satisfaction on tourists, besides good quality services which tend to form a positive image of tourism, so it is good for all parties.

2. The image of the tourism and service quality Bali Ngurah Rai International Airport positive effect on the tourist loyalty. It means that the quality of service coupled with a positive image of tourism can increase loyalty rating in a tourist area. This relates to the impressions of tourists during a tourist visit, so that tourists attraction can be improved.

3. traveler satisfaction positive effect on tourism image and loyalty of tourists visiting Bali. This means that the tourist satisfaction is one of the factors that shape a positive image of tourism, so this should be maintained and enhanced. Moreover, tourist satisfaction is the key towards loyalty, which if satisfied travelers to visit on a tourist attraction, then they will do revisit or recommend to others.

4. Tourism Citra positive effect on loyalty through satisfaction of tourists. This means that a positive image of tourism into loyalty trigger tourists to continue to visit. This means that in increasing the loyalty of tourists, not only oriented to the good image of tourism, but tourists should also be improved satisfaction for tourism destinations itself.

5. Quality of service Bali's Ngurah Rai International Airport is an effect on tourist loyalty through tourism image. This means that good quality services have an impact on the tourist loyalty is high, so the quality of service should be improved and developed, and continue to work together with the various parties to give a good image of tourism.

6. Overall rating opinion on the quality of service in the high category, with the highest quality opinions contained in the tangible dimension and the opinion of the lowest quality is below average are in the dimension of reliability. Results of quantitative analysis supported by qualitative data analysis, for example tourists interviewed said that the quality of service at Bali Ngurah Rai international airport is quite good and they promised to come back to Bali.

\section{Recommendation}

Based on the results of research and discussion in mind that the indicator is contacted airport officials tourists (empathy) and airport officials to keep promises indicator (timely) (reliable) still not give satisfaction to tourists. Considering both of these indicators are considered important by tourists, it is advisable to be pursued following improvements:

1. Addition of officers at the airport and placed in strategic places easily seen by tourists so that tourists easily contact airport personnel when in need of help / aid and airport officials should also be briefed so as not to give appointments or informs something to the tourists who cannot fulfilled.

2. prepaid taxi counter that used to exist in order to be returned existence, given the many tourists who complain as if it had been squeezed by private taxi drivers are a lot of wandering in the area of international arrivals terminal Bali's Ngurah Rai International Airport.

3. In order for enhanced cooperation of various stakeholders be it government, airport management, investors and the community to work together in creating a positive image of Bali tourism, so as to create a good tourism destination.

\section{Academic Suggestions}

To promote the development of science and benefits for the study, the researchers need to suggest things as follows:

1. Further research is expected to examine the deeper is not limited to the variables that have been studied (quality of service, satisfaction of tourists, tourism image and tourist loyalty), but the need for the addition of other causes variables associated with satisfaction, image and loyalty such as marketing public relations , word of mouth communication, local knowledge and so forth.

2. In subsequent studies, in particular regarding the variable quality of service, is expected to be developed in terms of measurement as well as supporting the broader theory, is not limited to tangible, 
empathy, reliability, responsiveness and assurance, are also expected to use a scope wider research object not only at the airport alone, but can be done comparative studies with other airports.

3. In further research can be developed respondents are more varied, not restricted to foreign tourists, but needs to be compiled with domestic tourists so that research results can be generalized and expected to be developed analytical models that already exist, taking into account other analysis tools are more accurate and updated.

\section{References}

Al-Abneh, M. (2013) 'Service Quality and its Impact on Tourist Satisfaction', Interdisciplinary Journal of Contemporary Research In Business, 4(12), pp. 164-177.

Ali, J. A. and Howaidee, M. (2012) 'The impact of service quality on tourist satisfaction in Jerash', Interdisciplinary Journal of contemporary research in business, 3(12), pp. 164-187.

Archana, R. and Subha, M. V (2012) 'A study on service quality and passenger satisfaction on Indian airlines', International Journal of Multidisciplinary Research, 2(2), pp. 50-63.

Dewi, I. J. (2012) 'Impelementasi dan Implikasi Kelembagaan Pemasaran Pariwisata yang Bertanggung jawab'. Pinus Book Publisher, Kementerian Kebudayaan dan Pariwisata Republik Indonesia.

Graeff Judith A (2006) Komunikasi Untuk Kesehatan dan Perubahan Perilaku. Yogyakarta: Gadjah Mada University Press.

Hossain, M. J. (2012) 'Impact of service quality on customer satisfaction: A case of tourism industry in Bangladesh', International Journal of Research in Finance \& Marketing, 2(2), pp. 1-25.

http://ojs.unud.ac.id/index.php/eot
Konecnik, M. (2004) 'Evaluating Slovenia's image as a tourism destination: A selfanalysis process towards building a destination brand', The Journal of Brand Management. Palgrave Macmillan, 11(4), pp. 307-316.

Kotler, P. and Keller, K. L. (2012) Marketing Management. New Jersey: Pearson Education International.

LeBlanc, G. and Nguyen, N. (1996) 'Cues used by customers evaluating corporate image in service firms: An empirical study in financial institutions', International Journal of Service Industry Management. MCB UP Ltd, 7(2), pp. 44-56.

Lopes, S. D. F. (2011) 'Destination image: Origins, developments and implications', PASOS. Revista de Turismo y Patrimonio Cultural, 9(2), pp. 305-315.

Manurung, D. S. H. (2009) 'Pengaruh kepuasan konsumen terhadap loyalitas merek pada pengguna kartu pra-bayar simpati'.

Martín-Cejas, R. R. (2006) 'Tourism service quality begins at the airport', Tourism Management. Elsevier, 27(5), pp. 874-877.

Meenaghan, T. and Shipley, D. (1999) 'Media effect in commercial sponsorship', European journal of marketing. Emerald Group Publishing Limited, 33(3/4), pp. 328-348.

Mosahab, R., Mahamad, O. and Ramayah, T. (2010) 'Service quality, customer satisfaction and loyalty: A test of mediation', International business research, 3(4), p. 72.

Movafegh, A. and Movafegh, A. (2013) 'The impact of service quality on tourist loyalty in Malaysian tourism industry', International Journal of Innovative Ideas, 13(1), pp. 1-19. 
Mowen, J. C. and Minor, M. (2002) 'Perilaku konsumen jilid 1', Penerjemah: Lina Salim. Erlangga. Jakarta.

Parasuraman (2009) Delivering Quality Service. New York: The Free Press.

Rahadhini, M. D. (2013) 'Pengaruh Citra Objek Wisata Umbul Tlatar Boyolali Terhadap Loyalitas Pengunjung Dengan Kepuasan Sebagai Variabel Mediasi', Ekonomi dan Kewirausahaan, 13(1).

Rahayu, A. (2012) 'Pengaruh Atribut Produk Wisata Terhadap Kepuasan Wisatawan'. Pascasarjana Universitas Udayana.

RP, A. K. and Sinambela, D. S. (2011) 'Analisis Kualitas Pelayanan, Serta Pengaruhnya Terhadap Kepuasan Pelanggan dan Loyalitas Pelanggan (Survei Pada Pengunjung SnowBay Waterpark TMII)', JRMSI-Jurnal Riset Manajemen Sains Indonesia, 2(2), pp. 110-129.

Sadeh, Ehsan, Asgari, Farid, Mousavi, Leila and Sina, S. (2012) 'Factors Affecting Tourist Satisfaction and Its Consequences', Journal of Basic and Applied Scientific Research, 2(2), pp. 1557-1560.

Saha, G. C. and Theingi (2009) 'Service quality, satisfaction, and behavioural intentions: A study of low-cost airline carriers in Thailand', Managing Service Quality: An International Journal. Emerald Group Publishing Limited, 19(3), pp. 350-372.

Som, A. P. M. and Badarneh, M. B. (2011) 'Tourist satisfaction and repeat visitation; toward a new comprehensive model', International Journal of Human and Social Sciences, 6(1), pp. 38-45.

\footnotetext{
Sugiyono (2012) Metode Penelitian Kuantitatif, kualitatif dan $R \& D$. Bandung: CV. Alfabeta.
}

Sulistiyani, E. (2010) 'Membangun Loyalitas Wisatawan Melalui Peningkatan Kualitas Obyek Wisata, Promosi dan Kepuasan Wisatawan di Kawasan Wisata Tawangmangu Karanganyar', Politeknik Negeri Semarang Journal Publish, pp. 161-165.

Weisesa (2008) Strategi Public Relation: Bagaimana strategi public relation dari 36 merek global dan lokal membangun citra, mengendalikan krisis dan merebut hati konsumen. Jakarta: PT. Gramedia Pustaka Utama.

Wibowo, L. A. and Yuniawati, Y. (2007) 'The Influence of Tourist Product Attribute and Trust to Tourist Satisfaction and Loyalty A Study of Mini Vacation in Bandung', Ringkasan Hasil Penelitian Dosen.

Zeithami, V. A. and Bitner, M. jo (2004) Service Marketing: Integrating Customer Focus Across The fim, 3 rd $E d$. New York: Mc Graw Hill. 